УДК 94 (477.7) «1960-1970»

DOI: https://doi.org/10.33782/eminak2019.2(26).295

\title{
ОКРЕМІ АСПЕКТИ СТАНУ СІЛЬСЬКОГО ГОСПОДАРСТВА ПІВДНЯ УКРАЇНИ У 60-х рр. ХХ ст.
}

\author{
Олександр Шарін \\ Миколаївський національний аграрний університет (Миколаїв, Україна) \\ e-mail: sharin@mnau.edu.ua \\ ORCID: https://orcid.org/0000-0001-5545-7436
}

У статті висвітлюються деякі аспекти розвитку сільського господарства на Півдні УРСР у 60-х рр. ХХ ст., а саме у Миколаӥвській, Одеській і Херсонській областях. Розвиток аграрного господарства розглядається у контексті реформування колгоспів і перетворення їх на радгоспи, подається динаміка скорочення чисельності колгоспів. Аналізуються спроби покращення роботи у сільському господарстві, за сприяння таких явищ, як шефська допомога та соціалістичні змагання. Автором на основі задекларованих директивних планів і результатів реформ, порівнюється динаміка електрифікації та механізації виробництва у період 1960-1970 рр.

Ключові слова: колгоспи, радгоспи, механізація, електрифікація, шефська допомога, соціалістичні змагання

У 60-х рр. ХХ ст. господарство Української РСР розвивалося на підставі директивних планів: семирічного (1959-1965 рр.) та восьмирічного (1966-1970 рр.). Економічне зростання республіки пов'язувалося у цей час з планомірним розвитком сільського господарства та комплексним використанням наявних виробничих можливостей.

У радянський період аграрний розвиток південноукраїнського регіону, певною мірою, висвітлювався у багатотомних виданнях «Історія народного господарства УРСР» 1 , «Історія селянства УРСР»2, «Історія робітничого класу»³, «Історія міст і сіл Української РСР»4 і статистичних щорічниках 5 . Проте слід зазначити, що названа література носила некритичний характер, матеріали розглядалися у контексті марксистсько-ленінської ідеології. У роботах $\quad$ В.Беззуба6, Л.Ю.Беренштейна7,

\footnotetext{
${ }^{1}$ Історія народного господарства Української РСР. У 3 т., 4 кн. Т. 3, кн. 1 Київ: Наук. думка, 1985. 464 с.; Історія народного господарства Української РСР. У 3 т., 4 кн. Т. 3, кн. 2 Київ: Наук. думка, 1987. 439 с.

2 Історія селянства Української РСР. Т. 2: Від Великого Жовтня до наших днів / Редкол.: I.I. Компанієць (відп. ред.) та ін. АН Української РСР. Інститут історії. Київ: Наукова думка, 1967. $536 \mathrm{c}$

3 Історія робітничого класу УРСР. Київ: Наукова думка, 1967. 567 с.

${ }^{4}$ Історія міст і сіл Української РСР. Одеська область. Київ: Головна редакція УРЕ АН УРСР, 1969. 911 с.; Історія міст і сіл Української РСР. Херсонська область. Київ: Головна редакція УРЕ АН УРСР, 1971. 792 с.; Історія міст і сіл Української РСР. Миколаївська область. Київ: Головна редакція УРЕ АН УРСР, 1971. $772 \mathrm{c}$.

5 Народне господарство Української РСР в 1970 році: статистичний щорічник. Київ: Статистика, 1971. 565 с.; Народное хозяйство Николаевской области. Статистический сборник. Одесса.: Маяк, 1970. 137 с.; Народное хозяйство Одесской области. Статистический сборник. Одесса, 1973. 215 с.; Народное хозяйство Херсонской области. Статистический сборник. Херсон, 1973. 183 с.

6 Беззуб В. Економічні проблеми розвитку сільського господарства УРСР на сучасному етапі Київ: Політвидав, 1974.112 с.

7 Беренштейн Л.Ю. Комуністи в боротьбі за неухильне піднесення сільського господарства (19531963 pp) // Український історичний журнал. 1963. № 5. С. 65-71.
} 
I.Н. Буздалова 8 , П.С. Костика ${ }^{9}$ та М.Д. Руденка ${ }^{10}$ досліджувалися окремі питання соціально-економічного розвитку українського села.

У незалежній Україні відбувається перегляд науково-дослідної парадигми відтворення певних аспектів розвитку сільського господарства у 1960-х рр. Нові акценти та методологічні підходи розроблено у роботах українськими науковцями: В.К. Баран ${ }^{11}$, М.В.Берегеда ${ }^{12}$, О.Д. Бойко13, В.М. Даниленко ${ }^{14}$, Т.I. Дерев'янкіна ${ }^{15}$, О.М. Завальнюк ${ }^{16}$, В.М. Ковальчук ${ }^{17}$, С.В. Кульчицький ${ }^{18}$, В.М. Литвин ${ }^{19}$.

Висвітлювалися питання загальноукраїнського розвитку сільського господарства. Аналіз опрацьованих матеріалів показав, що у наявній літературі комплексно не виокремлюються питання стану та розвитку аграрного сектору у Миколаївській, Одеській і Херсонській областях у 60-ті роки ХХ ст.

Метою представленої статті $\epsilon$ спроба порівняльного аналізу тенденцій розвитку сільського господарства в умовах змін і трансформацій на Півдні України у 60-ті рр. ХХ ст., а саме: Миколаївської, Одеської та Херсонської областей. Спираючись на статистичні показники враховується специфіка їх поступу.

У цей час в партійно-державному керівництві колгоспами спостерігався великий розрив між деклараційними гаслами та реаліями часу. На словах нібито відкидалося адміністрування, критикувалася жорстка централізація, колгоспам надавалося право на певну господарську самостійність та ініціативу. Управлінські структури мали проводити розробку й експериментальні розрахунки оптимізації перспективних планів на основі застосування економіко-математичних методів та електроннообчислювальних машин на підставі вдосконалення методів складання міжгалузево-

\footnotetext{
8 Буздалов И.Н. Материальное стимулирование и подъем колхозного производства. Москва: Колос, 1965. 248 с.; Буздалов И.Н. Экономическая эффективность интенсификации сельськохозяйственного производства. Москва: Колос, 1966. 390 с.

${ }^{9}$ Костик П.С. У боротьбі за технічне оснащення сільського господарства: (Діяльність Компартії України по створенню і дальшому розвитку матеріально-технічної бази сільського господарства південних областей УРСР, 1939-1975 рр.). Львів: Вища школа, 1980. 168 с.

10 Руденко М.Д. Економічні монологи: (нариси катастрофічної помилки). Б.м.: Сучасність, 1978. $200 \mathrm{c}$.

${ }^{11}$ Баран В.К. Україна: новітня історія (1945-1991рр.). Львів: Інститут українознавства ім. І. Крип'якевича НАН України, 2003. 670 с.

12 Брегеда М.В. Становлення населення нижньодунайського регіону до процесу десталінізації (1953-1964) // Наукові праці: Історичні науки. Вип. 127, Т. 140. Миколаїв: Вид-во ЧДУ імені Петра Могили, 2010. С. 53-59.

13 Бойко О.Д. Історія України у XX столітті (20-90-ті роки): Навч. посібник для студентів. Ніжин, 1994. 256 c.

14 Даниленко В.М. Українське село в добу реформ М. Хрущова // Історія українського селянства. У 2-х т. Київ: Наук. думка, 2006. Т. 2. С. 411-476.

15 Дерев'янкін Т.I. Відродження і спроби перебудови радянської економіки у післявоєнний період (1946-1991 рр.) // Актуальні проблеми економіки: науковий економічний журнал. 2009. № 7. С. 314.

16 Завальнюк О.М. Новітня аграрна історія України: навч. посібник. Кам'янець-Подільський: Абетка-НОВА, 2004. 288 c.

17 Ковальчук В.М. Історія економіки та економічної думки: навч. посібник. Київ: Знання, 2008. $647 \mathrm{c}$.

18 Кульчицький С.В. Спроби реформ (1956-1964) // Український історичний журнал. 1998. № 2. C. $102-114$.

19 Литвин В.М. Україна у другому повоєнному десятилітті (1956-1965). Київ: Вид. дім «Лі-Терра», 2004. 272 c.
} 
го балансу, розв'язання загальних проблем оптимізації планування 20 . Проте здійснювалося повернення до старих, командних методів управління, що вимагали безумовного виконання колгоспами вказівок адміністративного керівництва.

На початку 60-х рр. ХХ ст. екстенсивні методи господарювання, порушення елементарних правил агротехніки обернулися зниженням рентабельності виробництва. Колгоспи, здобувши, порівняно з минулим, свободу дій, так і не стали справжніми господарями на землі. Систему економічного примусу, що ставила їх у залежність від директивних органів, не було подолано.

Колгоспи втратили статус основної форми ведення сільського господарства. Поширювалася думка щодо первинності радгоспів, заснованих на державній (загальнонародній) власності. Радгоспи визнавалися більш зростаючою та послідовною соціалістичною формою ведення господарства на противагу колгоспам. Відтак, колгоспи оцінювались як перехідна форма, що мала бути замінена державною формою власності. Відповідно до цього й відбувалося масове перетворення колгоспів на радгоспи. На підставі статистичних джерел можна проаналізувати динаміку поступового зменшення чисельності колгоспів. У 1965 р. в Україні було 9553 колгоспи проти 13 тис. у 1950 р. У період до 1970 р. кількість колгоспів зменшилася на 3,7\% до 9 244. Так, у Херсонській області станом на 1960 р. було 182 колгоспи, у 1965 р. - 150, у 1970 р. - 146 колгоспів відповідно 21.

Скорочувалися всі основні показники колгоспів. Наприклад, загальна земельна площа зменшилася на 24\% у період з 1960 до 1970 р. Середньорічна кількість колгоспників зменшувалася на $31 \%$ у той же період. Але водночас основні засоби виробництва колгоспів неухильно зростали: із 1960 до 1970 р. основні засоби зросли на 206\%. Зокрема виробництву на 100 га землі виділялося 37,9 тис. крб. у 1970 р., у той час як у 1960 р. - 14,3 тис. крб. Рівень рентабельності сільськогосподарського виробництва колгоспів становив 51,5\% у 1960 р., 54,6\% у 1965 р. та 53,4\% у 1970 р.

В Одеській області кількість колгоспів зменшилася до 420 у 1971 р. порівняно із 448 у 1965 р., а кількість радгоспів зросла вже до 105 у 1970 р. із 101 у 1965 p.22. За аналогією можемо простежити тенденцію до зменшення колгоспів на Херсонщині із 182 у 1960 р. до 146 у 1970 р. та збільшення радгоспів із 60 у 160 р. до 126 у 1970 р.23. Миколаївська область мала певну відмінність: кількість колгоспів зросла з 224 у 1960 р. до 253 у 1965 р., проте і кількість радгоспів зростала з 62 у 1960 р. до 79 у 1965 p.24.

Влада прагнула переконати громадськість у тому, що зміни пропонувалися самими колгоспниками, які прагнули набути статусу робітників радгоспів. Саме радгоспники отримували гарантовану заробітну плату й користувалися державним централізованим пенсійним забезпеченням, чого в колгоспах у період, що нами розглядається, не було запроваджено. Підтвердженням цих ініціатив слугували заяви із місць до вищих органів влади. У досліджуваний період завдяки прийняттю низки постанов ЦК КПРС, зокрема Постанови ЦК КПРС і Ради СРСР «Про підвищення матеріальної зацікавленості колгоспників у розвитку суспільного виробництва» від

\footnotetext{
20 Історія народного господарства... Кн. 2. С. 58.

21 Коммунистическая партия Советского Союза в резолюциях и решениях съездов, конференций и пленумов ЦК. 1898-1970. Изд. 8-е, доп. и испр. Москва: Политиздат, 1971. Т. 7. 113 с.

22 Народное хозяйство Одесской области... С. 105-108.

23 Народное хозяйство Херсонской области... С. 79, 83.

24 Народное хозяйство Николаевской области... С. 60-61.
} 
16 травня 1966 р., у колгоспах здійснено перехід до гарантованої грошової оплати їх працівникам 25 . У тому ж році на Миколаївщині 253 колгоспи перейшли на внутрішньогосподарський розрахунок і грошову оплату праці.

Однією з особливостей ведення сільського господарства стала шефська допомога - добровільно-примусове залучення громадян з інших сфер народного господарства до сезонних сільськогосподарських робіт. До таких робіт переважно залучалися військовослужбовці, працівники державних установ, студенти, школярі. Найчастіше вони залучалися на збирання врожаю. Якщо студенти або працівники підприємств щорічно направлялися «на картоплю» в одне і те ж саме місце, то відповідні колгоспи та радгоспи називалися «підшефними».

У кінці 1960-х рр. у сільському господарстві постала проблема дефіциту працівників, оскільки вони не були економічно зацікавлені у «битві за врожай». 3 іншого боку, залучені до збирання врожаю містяни через низьку оплату також не мали зацікавленості в якості роботи та не мали необхідних навичок. Все це призводило до того, що під час збирання пропадала частина врожаю.

Шефська допомога, окрім використання громадян з інших сфер народного господарства для допомоги у зборі врожаю, - передбачала фінансування колгоспів і радгоспів, що відігравало позитивний ефект в їх розвитку. Наприклад, лише на Миколаївському Чорноморському суднобудівному заводі протягом 1954-1966 рр. для сільського господарства виконано замовлень на 50 млн. крб.26.

У 1970 р. на Миколаївщині 21 промислове підприємство здійснювало шефство над 95 колгоспами. За рік вони здали в експлуатацію 16 кормоцехів для великої рогатої худоби та свиней, пташник, консервний цех, зрошувальну систему на площі 1554 га, теплиці загальною площею 17,9 га. Тільки протягом восьмої п'ятирічки за їх участю введено в експлуатацію близько 250 кормоцехів, обладнано понад 640 кормокухонь, пущено понад 400 доїльних установок, виконано монтажні роботи для зрошення 5 тис. га земель, побудовано 40 га теплиць тощо 27.

Іншим прикладом є Одеський завод пресів. Підприємство у 1963 р. в порядку шефської допомоги обладнало три кормокухні колгоспу села Мардарівки. Усі тваринницькі ферми села електрифіковано, механізовано переробку кормів і водопостачання 28 .

Як зазначалося у довіднику партійного керівника - шефська допомога колгоспам і радгоспам повинна бути спрямована, перш за все, на прискорення комплексної механізації трудомістких процесів у рільництві та тваринництві, сільському та меліоративному будівництві; підготовку при промислових підприємствах механізаторських кадрів для села; сприяння у роботі з охорони праці, обладнанні стаціонарних і пересувних кабінетів, куточків з техніки безпеки; поліпшення діяльності сільських клубів, бібліотек, спортивних споруд, надання їм допомоги у культурно-побутовому обслуговуванні трудівників села 29.

Шефська допомога мала позитивну сторону, певною мірою сприяючи фінансуванню розвитку виробництва на селі. Щодо використання людського ресурсу з інших секторів, то це мало негативні наслідки, оскільки втрачалася частина урожаю, а

\footnotetext{
25 Збірник постанов і розпоряджень уряду УРСР. Київ, 1968. № 7. С. 86.

26 Плясков Л.А. Наш черноморский. 1897-1987. Москва: Мысль. 1989. С. 385.

27 Історія міст і сіл Української РСР. Миколаївська область... С. 66-67.

28 Історія міст і сіл Української РСР. Одеська область... С. 177.

29 Справочник партийного работника. Москва: Госполитиздат, 1957. С. 511.
} 
фахівці з міста займалися некваліфікованою роботою.

Одним із видів «пропагандистської» діяльності радянської системи, що мала сприяти розвитку сільського господарства, стали соціалістичні змагання. Економічне зростання республіки пов'язувалося у цей час із планомірним розвитком господарства, зокрема аграрного, та комплексним використанням наявних виробничих можливостей, крім того застосовувалися не економічні форми, що штучно створювали ажіотаж так званих соціалістичних змагань між трудовими колективами. Соціалістичне змагання - це радянський термін на позначення заходів переважно позаекономічного характеру задля підвищення продуктивності праці, в основу яких покладено не стільки стимули матеріального зацікавлення, скільки апеляції до «соціалістичної свідомості» працівників - під гаслом «віддати додаткові зусилля на розбудову соціалізму».

Наприклад, у 1960 р. на Одещині, з ініціативи механізатора Саратського району Г.І.Бочевара, поширився серед трактористів «рух швидкісників» 30 . Трактористи Одещини почали запроваджувати комплексну механізацію при вирощуванні кукурудзи та соняшнику, що передбачало зменшення собівартість продукції.

Соціалістичні змагання здебільшого організовувалися до певної знакової дати. Наприклад, підготовка до XXII з'їзду партії стала приводом створення серед колгоспників так званої «хвилі трудового і політичного піднесення». Проаналізовані нами джерела свідчать, що партійні організації розгорнули змагання з метою завершити всі сільськогосподарські роботи до дня відкриття з'їзду та завоювати право носити звання колгоспу ім. XXII з'їзду КПРС. Так, у 1962 р., відповідно до проголошених гасел, колгоспу імені Б. Хмельницького (с. Нейкове Одеської області) за «високі досягнення» було присвоєно ім'я «XXII з'їзду КПРС».

Як писали тоді у партійних документах і газетах, соціалістичні змагання набули поширення для підняття «ідейності» серед робітників. Наприкінці 1950-х рр. поширилася боротьба за звання ударника, бригади чи підприємства комуністичної праці. Учасники руху за комуністичне ставлення до праці, крім виробничих показників, брали на себе зобов'язання морально-етичного характеру (навчання, участь у громадському житті тощо). Такий вид стимулювання став невід'ємною складовою радянської системи, елементом штучного підвищення показників виробництва через створення так званого «змагального» ажіотажу довкола виробництва у тій чи іншій галузі. Особливого значення набували моральні заохочення це: почесні дипломи, значки, портрети переможців на дошках пошани; нагородження трудових колективів перехідним прапором переможця у соціалістичному змаганні. Наприклад, на Миколаївщині у 1960-х рр. у соціалістичних змаганнях брали участь радгоспи «Богданівна» Доманівського району, «Авангард» Жовтневого району, артілі ім. І.В. Мічуріна Кривоозерського району, «Україна» Веселинівського району. Вони нагороджені Ленінськими ювілейними почесними грамотами ЦК КПРС, Президії Верховної Ради СРСР, Ради Міністрів СРСР. За успіхи, досягнуті у розвитку сільськогосподарського виробництва та виконанні восьмого п'ятирічного плану, звання Героя Соціалістичної Праці присвоєно Л.Р. Апостоловій, М.С. Бойку, В.Г.Громовій, І.С.Дергачову, В.Г. Личку, І.М. Максимову, М.І. Стрекаловій, Х.І. Цушку, В.Г. Шевченкуз1.

Базуючись на ідеологічних вченнях комуністичних лідерів та враховуючи майс-

\footnotetext{
30 Історія міст і сіл Української РСР. Одеська область... С. 78.

31 Історія міст і сіл Української РСР. Миколаївська область... С. 67.
} 
терність ідеологів на місцях, вважалося, що соціалістичні змагання сприяли підняттю показників на виробництві та згуртовували колективи. За певних умов соціалістичні змагання сприяли за менше фінансування з боку держави більшій економічній рентабельності.

Проте, жодні моральні заохочення не могли інтенсифікувати аграрний сектор. Вирішення даного завдання було можливе лише на підставі електрифікації та механізації виробництва. Висуваючи амбітні плани у розвитку галузі, партійне керівництво країни визнавало, що це можливо здійснити лише завдяки одній «з визначальних умов виконання завдань із розвитку сільського господарства на 1959-1965 рр., що передбачала всебічне розширення механізації та 100\% електрифікацію виробництва»32. Держпланом УРСР на виконання грудневого (1958р.) Пленуму ЦК КРПС оперативно розроблено семирічний план електрифікації сільського господарства України. Згідно документу протягом 1959-1965 рр. планувалося електрифікувати село та збільшити показники втричі (порівняно з попереднім п'ятирічним планом). Із цією метою у червні 1959 р. Держплан і Міністерство сільського господарства СРСР спільно з представниками союзних республік на виконання постанови ХХІ з'їзду КПРС розробили та представили до ЦК партії пропозиції «Про заходи із забезпечення виконання плану електрифікації сільського господарства на 19591965 рр.»33. Якщо у 1950-ті рр. стояло завдання подати електроенергію у сільську місцевість, то у 1960-тірр. вже йшлося про ії використання у виробництві задля економії людського ресурсу.

Основними споживачами електроенергії в УРСР стали промисловість і будівництво, які споживали: 77,1\% - у 1960 р., 73,4\% - у 1965 р. та 70,4\% - у 1970 р. Сільське господарство споживало електроенергії: у 1960 р. - 3,9\%, у 1965 р. - 4,8\%, а в 1970 р. $-5,9 \%$.

Відповідно до статистичних показників, можемо простежити, що завдання, які ставилися ще у 1959 р. у Миколаївській області на 1965 р., а були виконані лише у 1968 р., коли саме завершено електрифікацію колгоспів і радгоспів на 100\%, а саме усі 253 радгоспи (для порівняння це на 60 колгоспів більше ніж у 1960 р. і лише на 5 більше ніж у 1965 р.). Тобто незважаючи на директивність поставлених завдань, їх неможливо було виконати. Відповідно збільшувалися обсяги виробленої енергії: якщо у 1960 р. вироблялося 10,6 млн. кВт, то до 1965 р. показники збільшились у 2,45 рази до 26 млн. кВт. Тенденція до зростання показників електрифікації радгоспів збільшувалася з кожним роком. У 1960 р. було електрифіковано 62 радгоспи, у 1965 р. - 79, а у 1969 р. - 94. Цей показник, починаючи від 1960 р., становив $100 \% 34$.

У 1967 р. на Одещині електрифіковано 431 колгосп, що становило 100\% показник, тобто планові цифри не були досягнені у визначений постановою Пленуму термін. Натомість станом на 1966 р. було електрифіковано 101 радгосп, що складало лише 99\%, а у 1967 р. електрифіковано 103 радгоспи, що склало вже 100\% показник 35 .

На Херсонщині 100\% показники електрифікації були досягнуті згідно запланованих термінів - у 1965 р. Кількість електрифікованих колгоспів у 1960 р. складала

\footnotetext{
32 Коммунистическая партия Советского Союза в резолюциях и решениях съездов, конференций и пленумов ЦК. 1898-1970. Изд. 8-е, доп. и испр. Москва: Политиздат, 1971. Т. 7. С. 442.

33 История социалистической экономики СССР. В 7 т. Т. 3. Москва: Наука, 1980. С. 4.

34 Народное хозяйство Николаевской области... С. 61.

35 Народное хозяйство Одесской области... С. 103-104.
} 
95\% від загальної кількості, а саме - 173, у подальшому електрифіковано, як зазначено, 100\%, хоча слід зазначити, що відбулося скорочення кількості колгоспів станом на 1965 р. до 150, а в 1970 р. - до 146. Електрифікація радгоспів відбувалася дещо повільнішими темпами: станом на 1960 р. електрифіковано лише 85\% від загальної кількості радгоспів, у 1965 р. відсоток збільшився до 98\%, і лише станом на 1970 р. усі 126 радгоспів електрифіковано 36 . На підставі наказу Міністерства будівництва електростанцій СРСР (№ 19-а від 02 лютого 1960 р.) у Новій Каховці організовано полігон із виробництва металоконструкцій. У подальшому, відповідно до наказу Міністерства енергетики та електрифікації СРСР від 31 січня 1967 р. № 16-а, полігон перетворено у Новокаховський завод із виробництва гідротехнічних металоконструкцій, що мало сприяти пришвидшенню електрифікації області.

Виходячи з аналізу електрифікації радгоспів і колгоспів, можемо зробити висновок, що галасливі заходи із забезпечення виконання плану електрифікації сільського господарства на 1959-1965 рр., були реалізовані вже після 1965 р.

Електрифікація сприяла збільшенню відсотка механізації робіт на тваринницьких фермах у колгоспах і радгоспах. Основні процеси у сільському господарстві, а саме доїння корів, подача води та роздача кормів, прибирання приміщень від навозу та стрижка овець на фермах було механізовано.

Найбільший відсоток механізації припадав на подачу води для великої рогатої худоби та свиней. Станом на 1970 р. у середньому на Півдні України це складало 90,1\%. Як свідчать проаналізовані нами статистичні джерела на Миколаївщині це склало - 92\%, в Одеській області - 84\%, Херсонській області - 92,5\%. Друге місце займала механічна стрижка овець, що станом на 1970 р. склала 86\%. Найменший відсоток механізації складала роздача кормів для великої рогатої худоби - 27,1\%: в Одеській області цей показник складав 19,5\%, Херсонській - 24\%, Миколаївській $38 \%$.

У 1960-х рр. в Україні збільшився парк сільськогосподарських машин та основних видів техніки. У Херсонській області кількість тракторів протягом 1960-х рр. збільшувалася: у 1960 р. налічувалося 7876 одиниць, у 1965 р. - 11009 одиниць, у 1970 р. - 12779 одиниць 37.

У 1960 р. в Миколаївській області було 8822 одиниці, у 1965 р. - 12391 одиниця, а в 1969 р. налічувалося 12976 одиниць тракторів ${ }^{38}$. У 1966 р. на Одещині парк тракторів налічував 26223 одиниці, а в 1970 р. - 19268 одиниць. Незважаючи на те, що політика радянського керівництва ставила за мету розвиток радгоспів, кількість техніки збільшувалася у колгоспах у 2-3 рази: наприклад, в Одеській області у 1966 р. налічувалося 11464 одиниці тракторів у колгоспах і 3523 одиниці тракторів у радгоспах, у 1970 р. - 13343 одиниці тракторів у колгоспах і 3741 одиниця тракторів у радгоспах ${ }^{39}$. У результаті збільшення виробничих потужностей за 19591973 рр. обсяг валової продукції Одеського заводу сільськогосподарського машинобудування збільшився у 3,2 рази 40 .

У Миколаївській області станом на 1960 р. налічувалося: 5394 одиниці тракторів

\footnotetext{
36 Народное хозяйство Херсонской области... С. 75.

37 Народное хозяйство Херсонской области. Статистический сборник. Херсон, 1973. С. 77.

38 Народное хозяйство Николаевской области. Статистический сборник. Одесса: Маяк, 1970. С. 62.

39 Народное хозяйство Одесской области. Статистический сборник. Одесса, 1973. С. 101.

40 Беззуб В. Економічні проблеми розвитку сільського господарства УРСР на сучасному етапі. Київ: Політвидав, 1974. 112 с.
} 
у колгоспах і 2853 - у радгоспах, у 1969 р. - 7749 одиниць тракторів у колгоспах і 4308 одиниць тракторів - у радгоспах.

Проте кількість таких важливих машин, як зернозбиральні комбайни, зменшилася загалом на 10,6\% по УРСР, а у південних областях - на 12,6\%. Найбільше зменшилася кількість комбайнів у Миколаївській області, а саме на 28\% - з 3515 у 1960 р. до 2735 у 1965 p.

Причиною такого становища стали прорахунки, що були допущені при перспективному плануванні виробництва нової сільськогосподарської техніки. Так, у 19591963 рр. через суб’єктивний підхід до цього важливого питання безпідставно було розширено випуск окремих видів машин, що не відповідали нагальним потребам аграріїв. Утворилася диспропорція - необгрунтовано велика кількість машин для вирощування та збирання кукурудзи, гороху та дефіцит тракторів для міжрядного обробітку, зернових сівалок, культиваторів.

Отже, розвиток аграрного господарства у 60-х рр. ХХ ст. відбувався у контексті реформування колгоспів і перетворення їх на радгоспи. Радянським керівництвом постійно робилися спроби поліпшення показників роботи у сільському господарстві різними видами діяльності, без урахування економічної доцільності. Як приклад автор статті наводить шефську допомогу та соціалістичні змагання.

Окремим засобом стимулювання розвитку сільського господарства стали електрифікація та механізація виробництва. Поставлені партійним керівництвом завдання електрифікації сільського господарства в УРСР вимагали впорядкування електропостачання, насамперед, колгоспів і радгоспів. Слід зазначити, що заходи визначені для забезпечення виконання семирічного плану електрифікації сільського господарства України, та Півдня України зокрема, у 1959-1965 рр. були реалізовані вже після 1965 р., окрім Херсонської області, де колгоспи та радгоспи 100\% електрифіковані у 1965 р. Як наслідок електрифікація сприяла збільшенню відсотка механізації робіт на тваринницьких фермах у колгоспах і радгоспах. Механізовано більшість процесів у сільському господарстві.

У 1960-х рр. в Україні збільшився парк сільськогосподарських машин та основних видів техніки. Але були й недоліки, наприклад, незважаючи на збільшення автопарку тракторів, зменшилася кількість зернозбиральних комбайнів. Причиною такого становища стали прорахунки, допущені при плануванні виробництва сільськогосподарської техніки.

\section{REFERENCES}

Baran, V.K. (2003). Ukraina: novitnia istoriia (1945-1991 rr.) [Ukraine: The Newest History (19451991)]. Lviv: Instytut ukrainoznavstva im. I. Krypiakevycha NAN Ukrainy [in Ukrainian].

Bezzub, V. (1974). Ekonomichni problemy rozvytku silskoho hospodarstva URSR na suchasnomu etapi [Economic problems of agricultural development of the Ukrainian SSR at the present stage]. Kyiv: Politvydav [in Ukrainian].

Breheda, M.V. (2010). Stanovlennia naselennia nyzhniodunaiskoho rehionu do protsesu destalinizatsii (1953-1964) [The formation of the population of the Lower Danube region to the process of deStalinization (1953-1964)]. Naukovi pratsi. Seriia «Istorychni nauky», 127 (140), 53-59 [in Ukrainian].

Berenshtein, L.Yu. (1963). Komunisty v borotbi za neukhylne pidnesennia silskoho hospodarstva (1953-1963 rr) [Communists in the struggle for the steady rise of agriculture (1953-1963)]. Ukrainskyi istorychnyi zhurnal, 5, 65-71 [in Ukrainian].

Boiko, O.D. (1994). Istoriia Ukrainy u XX stolitti (20-90-ti roky) [History of Ukraine in the XX century (2090-ies)]. Nizhyn [in Ukrainian].

Buzdalov, I.N. (1965). Materialnoe stimulirovanie i podiem kolkhoznogo proizvodstva [Material stimulation and raising of collective-farm production]. Moskva: Kolos [in Russian]. 
Buzdalov, I.N. (1966). Ekonomicheskaia effektivnost intensifikatsii selskokhoziaistvennogo proizvodstva [The economic efficiency of the intensification of agricultural production]. Moskva: Kolos [in Russian].

Danylenko, V.M. (2006). Ukrainske selo v dobu reform M. Khrushchova [Ukrainian village in the era of reforms of M. Khrushchev]. In Istoria Ukrainskoho selianstva. Vol. 2 (pp. 411-476). Kyiv: Naukova dumka [in Ukrainian].

Dereviankin, T.I. (2009). Vidrodzhennia i sproby perebudovy radianskoi ekonomiky u pisliavoennyi period (1946-1991 rr.) [Revival and attempts at restructuring the Soviet economy in the post-war period (1946-1991)]. Aktualni problemy ekonomiky: naukovyi ekonomichnyi zhurnal, 7, 3-14 [in Ukrainian].

Istoriia narodnoho hospodarstva Ukrainskoi RSR (1985-1987) [History of the national economy of the Ukrainian SSR]. T. 3, Ch. 1-2. Kyiv: Naukova dumka [in Ukrainian].

Istoriia robitnychoho klasu Ukrainskoi RSR (1967) [The history of the working class of the Ukrainian SSR]. Kyiv: Naukova dumka [in Ukrainian].

Istoriia mist $i$ sil Ukrainskoi RSR. Khersonska oblast (1971) [History of cities and villages of the Ukrainian SSR. Kherson region]. Kyiv: Holovna redaktsiia URE AN URSR [in Ukrainian].

Istoriia mist i sil Ukrainskoi RSR. Mykolaivska oblast (1971) [History of cities and villages of the Ukrainian SSR. Mykolaiv region]. Kyiv: Holovna redaktsiia URE AN URSR [in Ukrainian].

Istoriia mist i sil Ukrainskoi RSR. Odeska oblast (1969) [History of cities and villages of the Ukrainian SSR. Odessa region]. Kyiv: Holovna redaktsiia URE AN URSR [in Ukrainian].

Kompaniiets, I.I. (ed.) (1967). Istoriia selianstva Ukrainskoi RSR. T. 2: Vid Velykoho Zhovtnia do nashykh dniv [History of the peasantry of the Ukrainian SSR. T. 2: From Great October to the present]. Kyiv: Naukova dumka [in Ukrainian].

Kostyk, P.S. (1980). U borotbi za tekhnichne osnashchennia silskoho hospodarstva: (Diialnist Kompartii Ukrainy po stvorenniu $i$ dalshomu rozvytku materialno-tekhnichnoi bazy silskoho hospodarstva pivdennykh oblastei URSR, 1939-1975 rr.) [In the struggle for the technical equipment of agriculture: (Activities of the Communist Party of Ukraine for the establishment and further development of the material and technical base of agriculture of the southern regions of the USSR, 1939-1975)]. Lviv: Vyshcha shkola [in Ukrainian].

Kovalchuk, V.M. (2008). Istoria ekonomiky ta ekonomichnoi dumky [History of Economics and Economic Thought]. Kyiv: Znannia [in Ukrainian].

Kulchytskyi, S.V. (1998). Sproby reform (1956-1964) [Attempts for reform (1956-1964)]. Ukrainskyi istorychnyi zhurnal, 2, 102-114 [in Ukrainian].

Lytvyn, V.M. (2004). Ukraina u druhomu povoennomu desiatylitti (1956-1965) [Ukraine in the second post-war decade (1956-1965)]. Kyiv [in Ukrainian].

Pliaskov, L.A. (1989). Nash chernomorskii 1897-1987 [Our chernomorskii 1897-1987]. Moskva: Mysl [in Russian].

Rudenko, M.D. (1978). Ekonomichni monolohy: (narysy katastrofichnoi pomylky) [Economic monologues: (essays of catastrophic mistake)]. N.d.: Suchasnist [in Ukrainian].

Zavalniuk, O.M. (2004). Novitnia ahrarna istoria Ukrainy [The Newest Agrarian History of Ukraine]. Kamianets-Podilskyi: Abetka-NOVA [in Ukrainian].

\section{Oleksandr Sharin}

(Mykolayiv National Agrarian University, Mykolayiv, Ukraine)

ORCID: https://orcid.org/0000-0001-5545-7436

\section{Some Aspects of the State of Agriculture in the South of Ukraine in the $60 \mathrm{~s}$ of the $20^{\text {th }}$ century}

The paper uncovers certain aspects of the development of agriculture in the South of the USSR in the 1960s, namely in Mykolaiv, Odesa and Kherson Regions. The development of the agrarian sector is studied in the context of reforming the collective farms and transforming them into state farms. Based on the sources, the dynamics of reduction of their number in Mykolaiv, Odesa and Kherson Regions is presented. The attempts to improve the work in agriculture, with the assistance of such phenomena as patronage assistance and socialist emulations, are analyzed. Positive and negative effects of the above-mentioned phenomena are 
shown, for example, the use of citizens from other fields of the national economy, caused the partial loss of the harvest, and the fact that urban specialists were engaged in unskilled work. Not economic forms that artificially created the rush on so-called socialist emulations between state enterprises and individuals were applied.

The author, relying on the declared directive plans and the results of reforms, compares the dynamics of electrification and mechanization of production in the period of 1960-1970. The task of providing electricity to the countryside in order to save human resources is researched. The issues of increasing the percentage of mechanization of works on livestock farms, in collective farms and state farms are highlighted. The statistical indicators of mechanization of most processes in agriculture are given. An increase in the number of farming machines and major types of machinery is considered. Some shortcomings and faults made in the planning of agricultural machinery production are revealed.

Keywords: collective farms, state farms, mechanization, electrification, patronage assistance, socialist emulations 